\title{
Rheological Properties of Crackers Supplemented with Fish Protein Concentrate (FPC) \\ Abul-Fadel, M. M. ${ }^{1}$; S. M. Ibrahim ${ }^{2}$ and Shimaa S. Abd-Allah ${ }^{1}$ \\ ${ }^{1}$ Food Science and Technology Department, Agriculture Faculty, Al-Azhar Univ., Cairo. \\ ${ }^{2}$ Fish Processing Technology Lab, National Institute of Oceanography and Fisheries, Cairo.
}

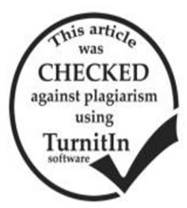

\section{ABSTRACT}

The addition effect of fish protein concentrate (FPC) on the nutritive value and rheological properties of crackers are the main objectives of this study. FPC was extracted from common carp flesh (5 and $10 \%$ levels) and its by-products (wastes) $(5 \%)$ were investigated. The results showed that the chemical composition (wet weight) of FPC obtained from flesh were $7.7 \%, 80.76 \%, 3.30 \%$, and $8.24 \%$ of moisture, protein, fat and ash content, respectively. The corresponding values of by- products were and $10.28 \%, 72.62 \%$, $3.12 \%$, and $13.98 \%$, respectively. Also, it was found that FPC contained high lipid content. Dough-water content is stable (13.70) in all trials. Dough-water absorption was similar in cases of control and 5\% flesh PC while it decreased in 10\% FPC and 5\% wastes PC crackers. Dough-stability increased up to 4.97 and 4.65 of crackers with flesh-PC and decreased in case of wastes-PC as compared to control (4.22). FPC could be improved the nutritive value, rheological properties as well as some sensory characteristics for supplemented crackers. In conclusion, $5 \%$ flesh protein concentrate was the best level for fortification crackers. Also, completely exploitation of carp fish species is very important to obtain FPC from flesh and by-products to overcome their defects and improve the environmental conditions.

Keywords: carp fish, crackers, rheological properties.

\section{INTRODUCTION}

Fish has a high nutritive value, its consumption not only meets many nutritive requirement of body but also it is useful to improve human health, and so many countries have tried to increase per capita consumption of its source (Dorvak, 2002). Fish protein concentrate (FPC) can be used as protein supplement to increase nutritive value of food. It is a healthy sustainable that sanitized produced from fishes in which, protein and other nutrients are more concentrated than in fresh fishes. Also, it can play an effective role in decreasing protein deficiency in some crowded parts in world that suffer from malnutrition as reviewed by FAO (2006); Cordova Murueta et al (2007) and Khoshkhoo et al., (2012). On the other hand, backed products such as bread, cookies and crackers are food containing significant quantities of cereal flours blended with other ingredients which are subsequently formed into distinctive shape and underwent a heat-processing step in baking oven (Cauvian and young, 2006). Crackers are popular bakery items in many parts of the world consumed by nearly all levels of society. They are ready to eat, of good nutritional quality, availability in different tastes, longer shelf life and available in different varieties at an affordable cost (Gandani et al., 2001). Consumers prefer to eat healthier foods in order to prevent non-communicable diseases. For this reason industry and researchers are involved in optimizing bread making technology to improve the variety, quality, taste and availability of food products such as bread and crackers (Hathorn et al., 2008). Several studies have been done to supplement crackers with FPC and it could be concluded that supplemented crackers were more suitable for children and teenagers and increased in the nutritive value (Shalaby and Yonis, 2002; Ibrahim 2009 and Shaviklo, 2015). Therefore, the current work studies the addition effect of fish protein concentrate (FPC) on the nutritive value and rheological properties of crackers. Supplementation with different levels of FPC obtained from carp flesh (5\% and 10\%) and 5\% from its by-products (wastes) were investigated.

\section{MATERIALS AND METHODS}

Materials

Fish samples

Common carp fish (Cyprinus carpio) samples were purchased from Banha Fish Market, EL-Qalubia Governorate during May, 2014. Raw fish samples were transported immediately using icebox within one hour to Fish Processing Technology Laboratory at El-Knater ElKhiria city, National Institute of Oceanography and Fisheries. Fish samples were carefully washed using tap water, manually filleted, washed again, drained and then packed in polyethylene bags. In addition, all fish by products; scales, skin, fins, viscera, and backbone were carefully washed, drained and then packed in polyethylene bags. Both packed fish samples; flesh and by-products were stored at $-28^{\circ} \mathrm{C}$ till processing.

\section{Crackers ingredients}

Wheat flour ( $72 \%$ extraction), fine granulated sucrose, Sodium bicarbonate, bakery yeast, Sodium chloride, shortening and water were obtained from local market.

\section{Technological processes \\ Extraction of fish protein concentrate (FPC)}

Fish protein concentrate (FPC) was extracted from both common carp flesh and its by-products wastes as described procedures by Refaat (1982) as follows: Water was added to minced raw fish flesh and wastes as the ratio $2: 1 \mathrm{v} / \mathrm{w}$. then it was cooked at $80^{\circ} \mathrm{C}$ for one hour. After that, they soaked in $1 \%$ acetic acid solution at $30^{\circ} \mathrm{C}$ for 45 min. and then dried at $75^{\circ} \mathrm{C}$ under vacuum for about 4 hours until moisture content reached to less $40 \%$. Azeotropic mixture prepared from ethanol (21\%) and hexane $(79 \%)$ was added to flesh and wastes samples at ratio of $2: 1 \mathrm{v} / \mathrm{w}$ for 1 hour at $79^{\circ} \mathrm{C}$. The extraction was repeated twice or three times using the same solvent mixture. Flesh and wastes samples were rapidly washed with the solvent in ratio of $1: 1.5$. The extracted samples were then desolventized at $65^{\circ} \mathrm{C}$ for $4-6$ hours to less than $10 \%$ moisture. The dried scrap was milled and sieved; the FPC obtained from carp flesh and its by-products were packaged in polyethylene bags and stored at $-18^{\circ} \mathrm{C}$ till processing. 


\section{Crackers processing}

Crackers were prepared according to the procedure of AACC (2000) with little changes especially at mixing procedures where $5 \%$ and $10 \%$ FPC obtained from flesh and 5\% FPC from fish by products (waste) were added to other ingredients. The crackers ingredients are illustrated in Table (1).

Table 1. The ingredients and its quantities used in crackers.

\begin{tabular}{lc}
\hline Ingredient & Quantity (g) \\
\hline Wheat flour (72\% extraction) & $100.0(14 \%$ moisture $)$ \\
Fine granulated sucrose & 1.03 \\
Salt (Sodium chloride) & 1.00 \\
Sodium bicarbonate & 0.8 \\
Baking soda & 0.2 \\
Shortening & 11.0 \\
Water & $40 \mathrm{ml}$ \\
\hline
\end{tabular}

Rheological properties testing:

Table (2) shows the Mixolab conditions used to prepare the crackers dough.

Table 2. Conditions of Mixolab used in this study.

\begin{tabular}{lc}
\hline Setting & Values \\
\hline Mixing speed & $80 \mathrm{rpm}$ \\
Dough weight & $75 \mathrm{~g}$ \\
Tank temperature & $30^{\circ} \mathrm{C}$ \\
Temperature 1ed step & $30^{\circ} \mathrm{C}$ \\
Duration 1ed step & $8 \mathrm{~min}$ \\
led temperature gradient & $15 \mathrm{~min}-4^{\circ} \mathrm{C} / \mathrm{min}$ \\
Temperature 2ed step & $90^{\circ} \mathrm{C}$ \\
Duration 2ed step & $7 \mathrm{~min}$ \\
2ed temperature gradient & $10 \mathrm{~min}-4^{\circ} \mathrm{C} / \mathrm{min}$ \\
Temperature 3ed step & $50^{\circ} \mathrm{C}$ \\
Duration 3ed step & $5 \mathrm{~min}$ \\
Total analysis time & $45 \mathrm{~min}$ \\
\hline
\end{tabular}

The typical Mixolab curve shows the following parameters:

1- Water absorption (\%): WA or the percentage of water required for the dough to produce a torque of 1.1 ;

2- Dough development time (min): DDT or the time to reach the maximum torque at $30^{\circ} \mathrm{C}$;

3- Stability ( $\mathrm{min}$ ) or time until the loss of consistency is lower than $11 \%$ of the maximum consistency reached during the mixing,

4- Initial maximum consistency (Nm): $\mathrm{C} 1$, used to determine the water absorption; torque at the end of the holding time at $30^{\circ} \mathrm{C}(\mathrm{Nm})$

5- Mechanical weakening $(\mathrm{Nm})$; the torque difference between $\mathrm{C} 1$ and $\mathrm{C} 1.2$;

6- Minimum consistency ( $\mathrm{Nm})$ : $\mathrm{C} 2$, the minimum value of torque produced by dough passage while being subjected to mechanical and thermal constraints;

7- Thermal weakening ( $\mathrm{Nm})$ : the difference between the $\mathrm{C} 1.2$ and $\mathrm{C} 2$ torques;

8- Pasting temperature $\left({ }^{\circ} \mathrm{C}\right)$ : the temperature at the onset of this rise in viscosity;

9- Peak torque $(\mathrm{Nm})$ : $\mathrm{C} 3$, the maximum torque produced during the heating stage;

10- Peak temperature $\left({ }^{\circ} \mathrm{C}\right)$ : the temperature at the peak viscosity; minimum torque $(\mathrm{Nm})-\mathrm{C} 4$,

11- Minimum torque reached during cooling to $50^{\circ} \mathrm{C}$; 12-breakdown torque $(\mathrm{Nm})$ : calculated as the difference 1054 between $\mathrm{C} 3$ and $\mathrm{C} 4$;

13-Final torque $(\mathrm{Nm})$ : $\mathrm{C} 5$, the torque after cooling at $50^{\circ} \mathrm{C}$;

14-Setback torque (Nm): the difference between $\mathrm{C} 5$ and $\mathrm{C} 4$ torque, is illustrated in Figure (1).

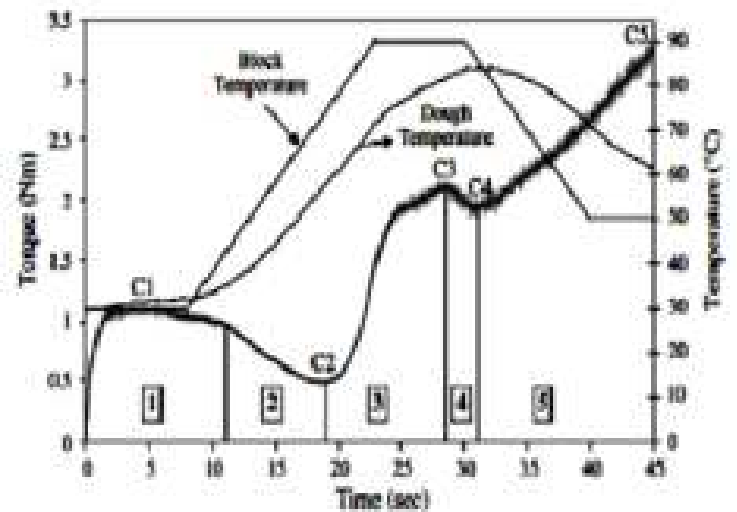

Fig. 1. Description of a typical curve obtained in the Mixolab. The numbers indicate the different areas detected in the curve according to the wheat bread dough changes: (1) Dough development; (2) Protein reduction during heating; (3) Starch gelatinization; (4) Amylase activity; and (5) Starch gelling is due to cooling (Kahraman et al., 2008).

Analytical Methods

Proximate analysis of fish protein concentrate (FPC) and crackers were determined according to the procedures of the AOAC, (2000). Total carbohydrates content was calculated by difference as described by Maclean, et al., (2003). Dough rheological properties; water absorption, stability, viscosity, dough development, protein breakdown, starch gelatinization, amylase activity and starch gelling were performed by Mixolab (Chopin, Tripette et Renaud, Paris, France) according to AACC, (2010). Sensory characteristic were evaluated as described method by AACC (2000) with change 10 score instead of 7 score. All data was statistically analyzed by using SPSS (ver. 16).

\section{RESULTS AND DISCUSSION}

Proximate chemicals composition of fish protein concentrate FPC:

The proximate analysis of FPC obtained from common carp flesh and co-products (wastes) are presented in Table (3). Results show that the FPC from flesh contained $7.7 \%, 80.76 \%, 3.60 \%$ and $8.24 \%$ for moisture, protein, fat and ash content, respectively. The corresponding values of FPC from fish waste were $10.28 \%, 72.62 \%, 3.12 \%$ and $13.98 \%$, respectively. Also, it could be found that FPC produced was high lipid content. These results are in agreement with those of by Cordova Murueta et al., (2007); Ibrahim (2009) and Khoshkhoo et al., (2012). 
Table 3. The proximate analysis (ww) of (FPC) obtained from common carp flesh and co-products.

\begin{tabular}{lcc}
\hline Constituent & \multicolumn{2}{c}{ FPC obtained from common carp; } \\
\cline { 2 - 3 }$(\boldsymbol{\%})$ & Flesh & Waste \\
\hline Moisture & $7.70 \pm 1.73$ & $10.28 \pm 1.73$ \\
Protein & $80.76 \pm 0.76$ & $72.62 \pm 0.76$ \\
Fat & $3.30 \pm 0.15$ & $3.12 \pm 0.18$ \\
Ash & $8.24 \pm 0.79$ & $13.98 \pm 0.79$ \\
\hline
\end{tabular}

Data are given as mean values \pm SD $(n=3)$.

Chemical composition of produced crackers supplemented with FPC

The proximate analysis for both control and crackers supplemented with 5\% and 10\% FPC from flesh and 5\% FPC from wastes are shown in Table (4). Control sample contained $4.82 \%$ moisture, $21.95 \%$ protein,
$25.97 \%$ fat, 5.58 and $41.68 \%$ carbohydrate content. On the other hand, 5\% FPC flesh-crackers contained 5.4\%, $32.09 \%, 29.64 \%, 3.31 \%$, and $29.56 \%$, respectively. In case of $10 \%$ FPC flesh-crackers chemicals composition were $5.81 \%, 33.83 \%, 29.20 \%, 4.36 \%$ and $26.8 \%$, respectively. Concerning crackers supplemented with 5\% FPC from waste, they contained $5.58 \%, 32.02 \%, 28.51 \%, 3.70 \%$ and $30.20 \%$, respectively. Also, the results show there are significance differences $(P \leq 0.05)$ between treatments and control sample in moisture and protein content. However, there are no significance differences $(P \leq 0.05)$ between treatments and control in case of fat content. Statistical analysis also shows there is a significant different $(P \leq$ 0.05 ) in ash content of at $5 \%$ flesh.

Table 4. The proximate analysis for both control and crackers supplemented with 5\% and $10 \%$ FPC from flesh and waste.

\begin{tabular}{lcccc}
\hline Constituents & \multirow{2}{*}{ Control } & FPC from flesh at levels; & FPC from waste at \\
\cline { 2 - 3 } & & $\mathbf{5 \%}$ & $\mathbf{1 0 \%}$ & \begin{tabular}{c} 
level; 5\% \\
\cline { 2 - 3 }
\end{tabular} \\
\hline Moisture & $4.82^{\mathrm{b}} \pm 0.22$ & $5.40^{\mathrm{a}} \pm 0.17$ & $5.81^{\mathrm{a}} \pm 0.39$ & $5.58^{\mathrm{a}} \pm 0.51$ \\
Protein & $21.95^{\mathrm{c}} \pm 2.00$ & $32.09^{\mathrm{a}} \pm 2.00$ & $33.83^{\mathrm{ab}} \pm 3.99$ & $32.02^{\mathrm{a}} \pm 2.00$ \\
Fat & $25.97^{\mathrm{bc}} \pm 3.48$ & $29.64^{\mathrm{ab}} \pm 0.12$ & $29.20^{\mathrm{ab}} \pm 0.97$ & $28.50^{\mathrm{ab}} \pm 0.39$ \\
Ash & $5.58^{\mathrm{a}} \pm 0.45$ & $3.31^{\mathrm{c}} \pm 0.67$ & $4.36^{\mathrm{ab}} \pm 0.55$ & $3.90^{\mathrm{bc}} \pm 0.58$ \\
$*_{\text {Carbohydrate }}$ & 41.68 & 29.56 & 26.8 & 30.00 \\
Energy (Cal) & 496.25 & 513.36 & 504.24 & 505.38 \\
\hline
\end{tabular}

*Carbohydrate was calculated by differences.

Data are given as mean values $\pm S D(n=3)$

Different letters $(\mathrm{a}, \mathrm{b}, \mathrm{c}$ or $\mathrm{d})$ within a row indicate significant differences $(\mathrm{P}<0.05)$.

Also, results showed that the water, protein and lipid content increased in all treatments and this phenomenon is confirmed by Venugopal (2006) who reported that nutritive value of cereal proteins could be increased when combined with fish protein flour FPF. Thus, the addition of $3 \%$ of FPF to wheat flour (protein content, $10.4 \%$ ) increased its protein content to $12.4 \%$. Also, Ibrahim (2009) found that $5 \%$ FPC from tilapia byproducts was the best level of fortification of salt biscuits. In this study, 5\% flesh protein concentrate was the best level for fortification crackers.
Rheological properties of crackers dough

The rheological properties of dough crackers supplemented with FPC as compared to control sample are shown in Table (5) and Fig. (2). Dough-water content is stable (13.70) in all trials. Dough-water absorption was similar in cases of control and 5\% flesh FPC while it decreased in 10\% FPC and 5\% wastes FPC dough crackers. Dough-stability increased up to 4.97 and 4.65 of dough crackers with flesh-FPC and decreased in case of wastes-FPC as compared to control (4.22).

Table 5. The rheological properties of crackers supplemented with 5\% and $10 \%$ FPC from and 5\%FPC from wastes flesh compared with control sample.

\begin{tabular}{|c|c|c|c|c|c|}
\hline \multirow{3}{*}{ Parameter } & & \multirow{3}{*}{ Control } & \multicolumn{3}{|c|}{ Levels of FPC } \\
\hline & & & \multicolumn{2}{|c|}{ Flesh } & \multirow{2}{*}{$\begin{array}{c}\text { Waste } \\
5 \%\end{array}$} \\
\hline & & & $5 \%$ & $10 \%$ & \\
\hline Moisture content & & 13.70 & 13.70 & 13.70 & 13.70 \\
\hline Water absorption & & 57.1 & 57.1 & 55.7 & 55.2 \\
\hline Stability(min) & & 4.22 & 4.97 & 4.65 & 3.88 \\
\hline Dough & Formation time (min) & 1.00 & 0.97 & 0.92 & 0.92 \\
\hline Development & Torque $(\mathrm{Nm})$ & 1.048 & 1.078 & 1.082 & 1.084 \\
\hline $\mathrm{C} 1$ & Dough temp. $\left({ }^{\circ} \mathrm{C}\right)$ & 30.00 & 30.40 & 30.10 & 30.90 \\
\hline Protein & Formation time (min) & 15.92 & 16.72 & 16.62 & 16.20 \\
\hline Breakdown & Torque (Nm) & 0.380 & 0.454 & 0.392 & 0.344 \\
\hline $\mathrm{C} 2$ & Dough temp. $\left({ }^{\circ} \mathrm{C}\right)$ & 57.20 & 58.00 & 56.10 & 57.90 \\
\hline \multirow{3}{*}{$\begin{array}{l}\text { Starch gelatinization } \\
\mathrm{C} 3\end{array}$} & Formation time (min) & 22.18 & 24.22 & 23.07 & 23.10 \\
\hline & Torque $(\mathrm{Nm})$ & 1.863 & 1.976 & 1.796 & 1.869 \\
\hline & Dough temp. $\left({ }^{\circ} \mathrm{C}\right)$ & 82.10 & 83.60 & 82.00 & 84.30 \\
\hline \multirow{3}{*}{$\begin{array}{l}\text { Amylase activity } \\
\text { C4 }\end{array}$} & Formation time (min) & 31.07 & 32.02 & 33.52 & 31.10 \\
\hline & Torque $(\mathrm{Nm})$ & 1.249 & 1.360 & 1.187 & 1.649 \\
\hline & Dough temp. $\left({ }^{\circ} \mathrm{C}\right)$ & 87.7 & 85.5 & 82.2 & 87.6 \\
\hline \multirow{3}{*}{$\begin{array}{l}\text { Starch gelling } \\
\text { C5 }\end{array}$} & Formation time (min) & 45.02 & 45.00 & 45.02 & 45.60 \\
\hline & Torque $(\mathrm{Nm})$ & 1.941 & 1.845 & 1.678 & 2.439 \\
\hline & Dough temp. $\left({ }^{\circ} \mathrm{C}\right)$ & 54.00 & 56.60 & 56.10 & 55.00 \\
\hline
\end{tabular}



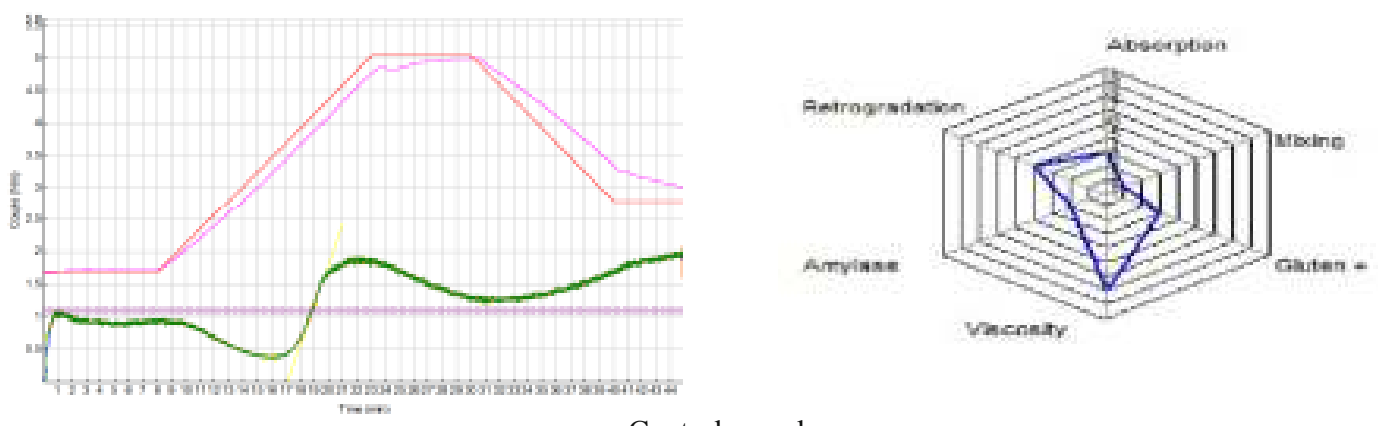

Control sample
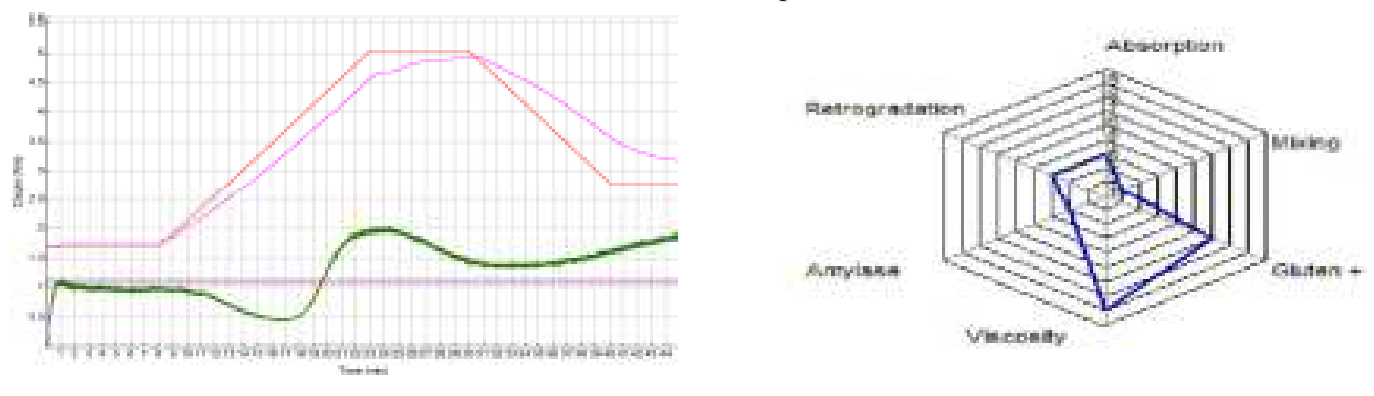

$5 \%$ FPC flesh
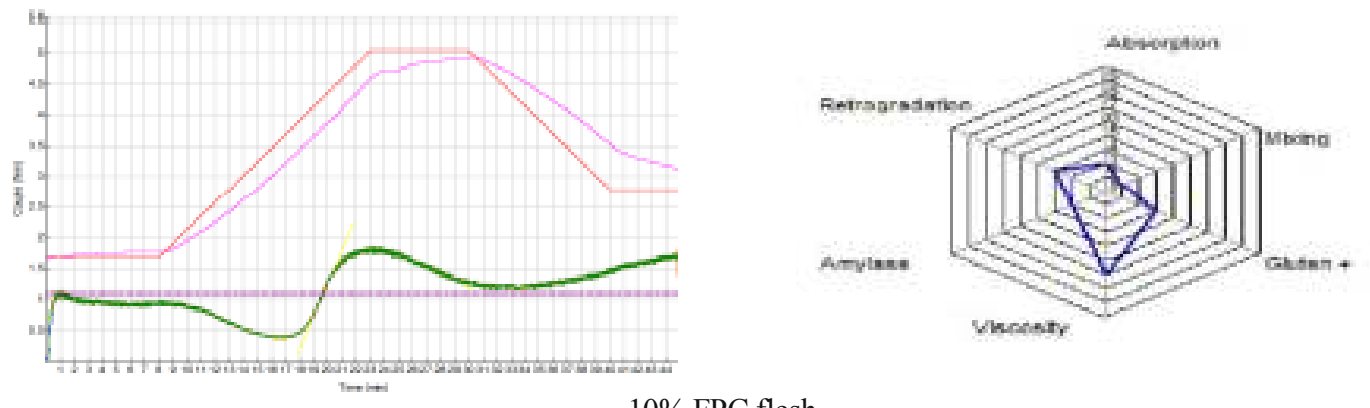

$10 \%$ FPC flesh
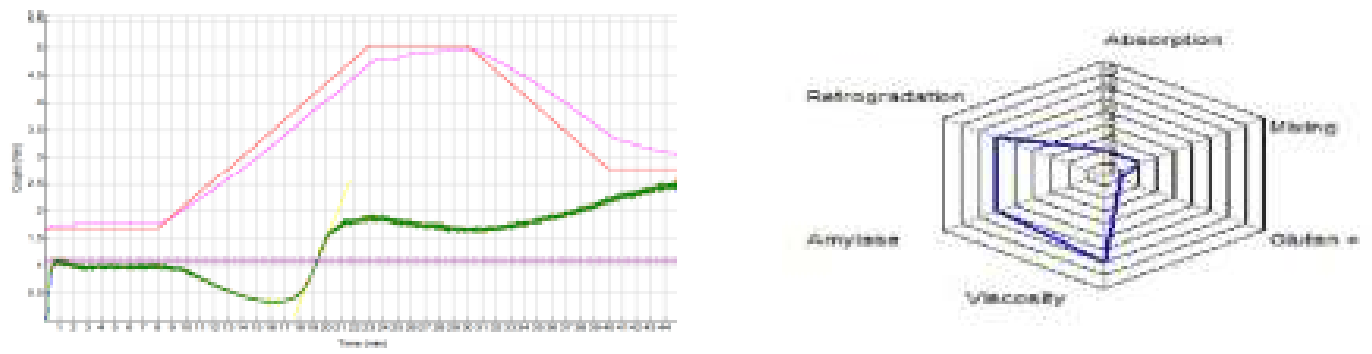

$5 \%$ FPC waste

Fig. 2. The rheological properties of crackers supplemented with 5\% and $10 \%$ FPC from flesh and 5\% FPC from wastes compared with control sample.

Concerning dough development (C1), formation time (min) is lower in dough crackers supplemented by FPC than control sample. Dough-Torque $(\mathrm{Nm})$ and temperatures values of treatments increased as affected by FPC added compared to control. Besides dough-protein breakdown (C2), FPC led to increase in formation time, Torque (except 5\%wastes PC) and temperature (except $10 \%$ flesh PC) values of supplemented crackers as compared control. With regard to dough-starch gelatinization (C3), FPC led to increase in formation time, Torque and temperature (except $10 \%$ flesh PC) values of supplemented crackers as compared control. Formation time and Torque (except 10\%flesh PC) values increased whereas temperature reduced of amylase activity (C4) in supplemented crackers as compared control. In addition to dough-starch gelling (C5), formation time was slightly changed, Torque $(\mathrm{Nm})$ values decreased in cases of 5 and $10 \%$ flesh PC samples and increased in case of $5 \%$ waste PC sample when comparing to control sample. Generally, FPC increased in rheological properties; formation time (min), Torque $(\mathrm{Nm})$ and temperatures $\left({ }^{\circ} \mathrm{C}\right)$ of dough development $(\mathrm{C} 1)$, protein breakdown (C2), starch gelatinization (C3), amylase activity (C4) and starch gelling (C5) for studied crackers. These results are in accordance with those reported by Rodriguez-Sandoval et al; (2012); El-Badry et al (2014) and Abd-elazim (2017) 
who reported that the increment in dough-water absorption may be attributed to increase of protein percentage in dough.

Sensory evaluation of produced crackers supplemented with FPC

Table (6) shows sensory tests of crackers supplemented with 5\% and 10\% Flesh PC and 5\% waste PC. Surface appearance, interior appearance and eating characteristics of crackers were evaluated. High scores were given for surface shape property of control and color of crackers with 5\% flesh PC. The same trend was found in case interior appearances of crackers with $10 \%$ flesh PC. Also, high scores were given for texture of control, mouth feel of crackers with $10 \%$ flesh PC and flavor of crackers with 5\% wastes PC. Results demonstrate there is a significant difference $(P \leq 0.05)$ in shape of surface appearance between treatments and control sample. The same trend was found in crackers $(10 \%$ FPC) compared to other ones. Also, there is a significant difference in shape of interior appearance of crackers 5\% FPC however, there is no found of color property. Concerning eating characteristics, there are significant differences $(P \leq 0.05)$ in crackers $(10 \% \mathrm{FPC})$ in both texture and flavor and in mouth feel property of crackers ( $5 \%$ waste PC) compared other ones. In general, FPC could be improved surface color, interior appearance and eating characteristics in particular mouth feel and flavor of crackers.

Table 6. Sensory evaluation of crackers supplemented with $5 \%$ and $10 \%$ FPC obtained from carp flesh and $5 \%$ waste.

\begin{tabular}{|c|c|c|c|c|}
\hline \multirow[b]{2}{*}{ Characteristic } & \multicolumn{4}{|c|}{ Crackers; } \\
\hline & Control & $\begin{array}{c}\text { Flesh PC } \\
\mathbf{5 \%}\end{array}$ & $\begin{array}{c}\text { Flesh PC } \\
10 \%\end{array}$ & $\begin{array}{c}\text { Waste PC } \\
\mathbf{5 \%}\end{array}$ \\
\hline \multicolumn{5}{|c|}{ Surface appearance } \\
\hline Shape & $9.3^{\mathrm{a}}$ & $8.4^{\mathrm{b}}$ & $9.0^{\mathrm{ab}}$ & $8.6^{\mathrm{ab}}$ \\
\hline Color & $9.0^{\mathrm{a}}$ & $9.1^{\mathrm{a}}$ & $8.4^{\mathrm{b}}$ & $8.9^{\mathrm{a}}$ \\
\hline \multicolumn{5}{|c|}{ Interior appearance } \\
\hline Shape & $8.7^{\mathrm{a}}$ & $8.6^{\mathrm{a}}$ & $8.8^{\mathrm{a}}$ & $8.3^{\mathrm{b}}$ \\
\hline Color & $8.9^{\mathrm{a}}$ & $9.0^{\mathrm{a}}$ & $9.1^{\mathrm{a}}$ & $8.6^{\mathrm{a}}$ \\
\hline \multicolumn{5}{|c|}{ Eating characteristics } \\
\hline Texture & $8.9^{\mathrm{a}}$ & $8.7^{\mathrm{a}}$ & $7.9^{\mathrm{b}}$ & $8.4^{\mathrm{ab}}$ \\
\hline Mouth feel & $8.8^{\mathrm{a}}$ & $7.9^{\mathrm{b}}$ & $9.1^{\mathrm{a}}$ & $8.9^{\mathrm{a}}$ \\
\hline Flavor & $9.0^{\mathrm{a}}$ & $9.1^{\mathrm{a}}$ & $7.4^{\mathrm{b}}$ & $9.3^{\mathrm{a}}$ \\
\hline
\end{tabular}

Data are given as mean values $\pm \mathrm{SD}(\mathrm{n}=3)$

Different letters (a, b, c or d) within a row indicate significant differences $(\mathbf{P}<\mathbf{0 . 0 5})$.

\section{CONCLUSION}

Common carp has a successful cultured and low price in Egypt however unacceptable for most consumers because it contains intramuscular bones and spines and also bad smell. In conclusion, $5 \%$ flesh protein concentrate was the best level for fortification crackers. Also, completely exploitation of carp fish species is very important to obtain FPC from flesh and by-products to overcome their defects and improve the environmental conditions.

\section{REFERENCES}

AACC (2000). A proved method of analysis. The American Association of Cereal Chemists. Published by American Association of Cereal Chemists, $10^{\text {th }}$ ed. St. Paul, Minnesota, USA.
AACC (2010). Approved Methods of American Association of Cereal Chemists. Published by American Association of Cereal Chemists, Inc. St. Paul, Minnesota, U.S.A.

Abd-elazim, E.I.I., (2017) Chemical, technological and nutritional studies on some gluten free bakery products. Ph,D. Thesis faculty of Agriculture, ALAzher University.

AOAC (2000). Association of official analytical methods. Official Methods of Analysis. $16^{\text {th }}$ ed. Arlington, Virginia. USA.

Cauvain, S. and Young, L. (2006). The nature of baked product structure. in: Cauvain, S., Young, L. (Eds.), Baked Products: Science, Technology and Practice, Blackwell publishing, Oxford, United Kingdom.

Cordova Murueta, J. H.; Navarrete del Toro, M. L., and Garcia Carreno, F. (2007). Concentrates of fish protein from bycatch species produced by various drying processes. Food Chemistry, 100, 705-711.

Dvorak, P. (2002). Something fishy is going on in Japan in the ice cream. Journal of Wall Street. Eastern edition. Pg.A.1.

El-Badry, N.; El-Waseif, M. A.; Badr, S.A. and Ali, H. E. (2014). Effect of Addition Watermelon Rind Powder on the Rheological, Physiochemical and Sensory Quality Attributes of Pan Bread Middle East Journal of Applied Sciences, 4(4): 1051-1046.

El-Shreif, S.A.A. (2005). Effect of storage period on the quality of fish protein concentrate and isolate prepared from Fayom fisheries waste .J. of home economic, Minufiya Univ., 15 (1-2): 25-40.

FAO (2006). Fish Protein Concentrate, fish flour, fish hydrolyzate. Animal Feed resource information system. http://www .fao. org/ ag/ aga/agap/ frg/afris/ Data/334.HTM

Gandani, A. P.; Kotawaliwale, N.;Kawaka, J.;Srivastava, D.C.; Parihar, V.S. and Raghu Nadh, P. (2001). Effect of incorporation of defatted soy flour on the quality of sweet biscuits. Journal of Food Science and Technology, 38: 502-503.

Hathorn, C. S., M. A. Biswas, P. N., Gichuhi, and A. C. Bovell-Benjamin, 2008. Comparison of chemical, physical, micro-structural, and microbial properties of breads supplemented with sweet potato flour and high-gluten dough enhancers. LWT - Food Science and Technology, 41(5): 803-815.

Ibrahim S.M 2009 Evaluation of Production and Quality of Salt-Biscuits Supplemented with Fish Protein Concentrate World Journal of Dairy \& Food Sciences 4 (1): 28-31, 2009

Kahraman, K., O. Sakyyan, S., Ozturk, H. Koksel, G. Sumnu, and A. Dubat, 2008. Utilization of mixolab to predict the suitability of flours in terms of cake quality. European Food Research and Technology, 227: 565-570.

Khoshkhoo Zh.; Motalebi, A. A. ; Razavilar, V. ; Khanipour, A. A. (2012). Protein and lipid changes of FPC produced from Caspian Sea Kilkas in VP and MAP during storage at different temperatures. Iranian Journal of Fisheries Sciences 11(2) 338346. 
Maclean, W., Harnly, J., Chen, J., Chevassus-Agnes, S., Gilani, G., Livesey, G., and Warwick, P. (2003). Food energy- methods of analysis and conversion factors. Food and Agriculture Organization of the United Nations Technical Workshop Report (Vol. 77).

Rodriguez-Sandoval, E.; Sandoval, G and CortesRodrigues, M(2012) Effect of quinoa and potato flours on thermo mechanical and bread making properties of wheat flour. Brazilian Journal of Chemical Engineering, 29(3): 503-510.

Refaat, O.C.A.(1982) Utilization of fish flesh and viscera in production of protein concentrate for human nutrition. M.Sc. Thesis, faculty of Home Economics, Helwan University.
Shalaby, A.O. and Yonis, A.A.M. (2002). Effect of adding maize flour and texture soy protein flour on the quality of biscuits, $\mathrm{J}$ of Home Economic, Minoufiya univ., 12(3): (85-97).

Shaviklo, A.R. (2015). Development of fish protein powder as an ingredient for food applications: a review J. Food Sci. Technol. 52(2):648-661

Venugopal, V. (2006). Seafood processing adding value through quick freezing, retort-able packaging and cook-chilling. Taylor \& Francis Group, CRC, Boca Raton, pp: 425-447.

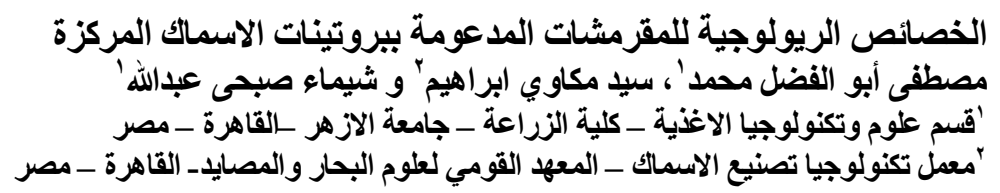

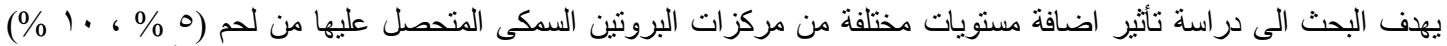

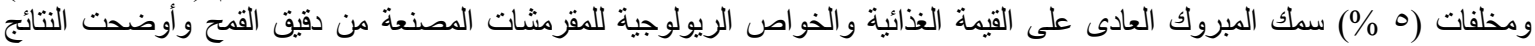

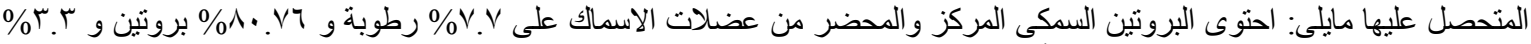

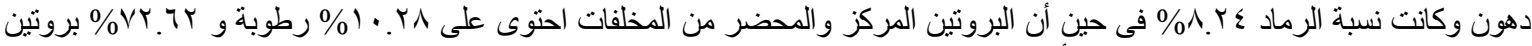

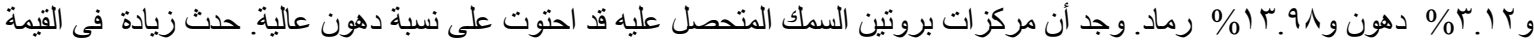

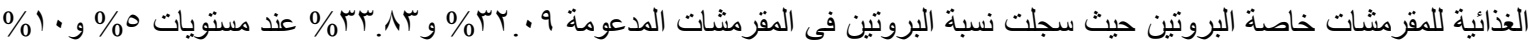

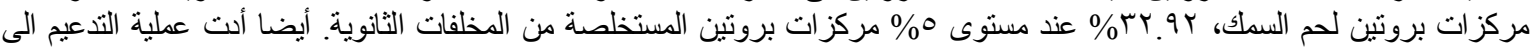

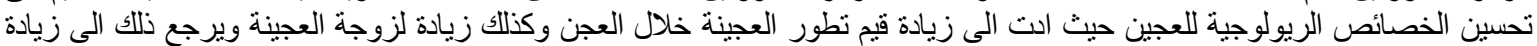

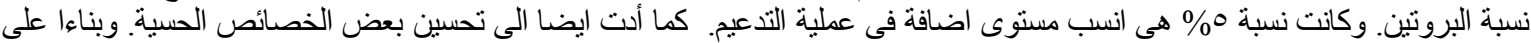

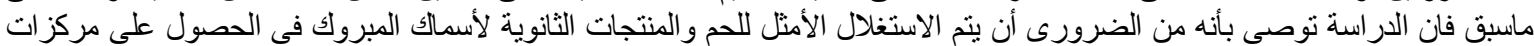

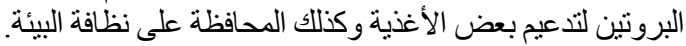

